$1-1-1893$

\title{
Catalogue of West Virginia Scolytidae and their enemies : with list of trees anb shrubs attacked
}

\author{
A. D. Hopkins
}

Follow this and additional works at: https://researchrepository.wvu.edu/ wv_agricultural_and_forestry_experiment_station_bulletins

\section{Digital Commons Citation}

Hopkins, A. D., "Catalogue of West Virginia Scolytidae and their enemies : with list of trees anb shrubs attacked" (1893). West Virginia Agricultural and Forestry Experiment Station Bulletins. 31.

https://researchrepository.wvu.edu/wv_agricultural_and_forestry_experiment_station_bulletins/31 @ WVU. It has been accepted for inclusion in West Virginia Agricultural and Forestry Experiment Station Bulletins by an authorized administrator of The Research Repository @ WVU. For more information, please contact ian.harmon@mail.wvu.edu. 


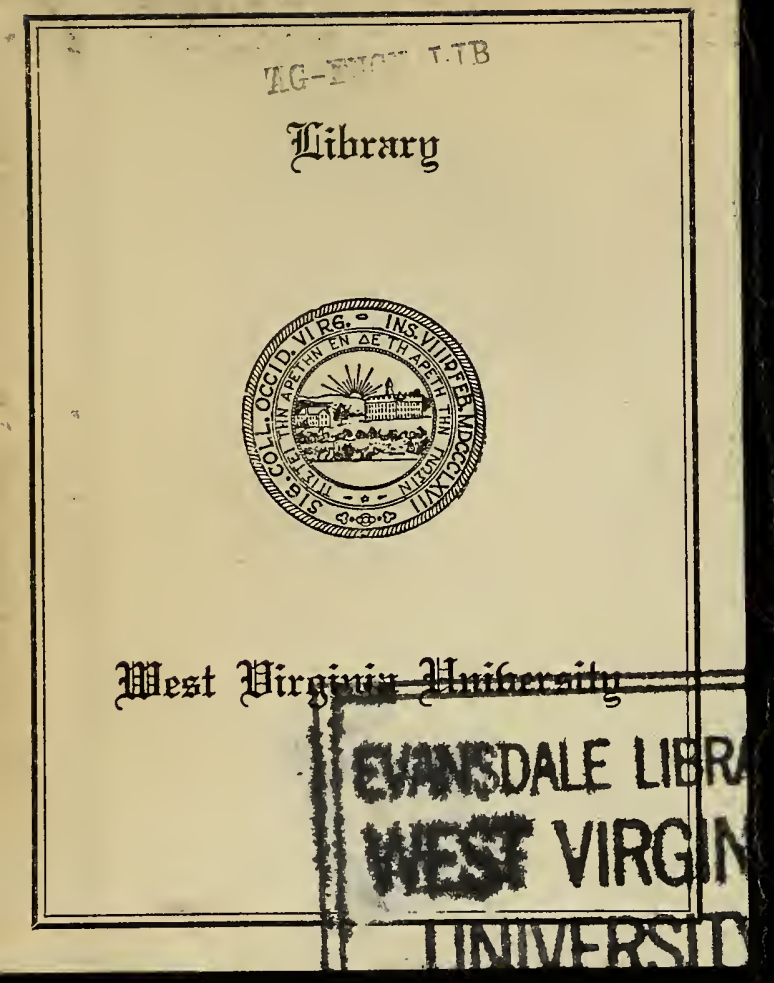



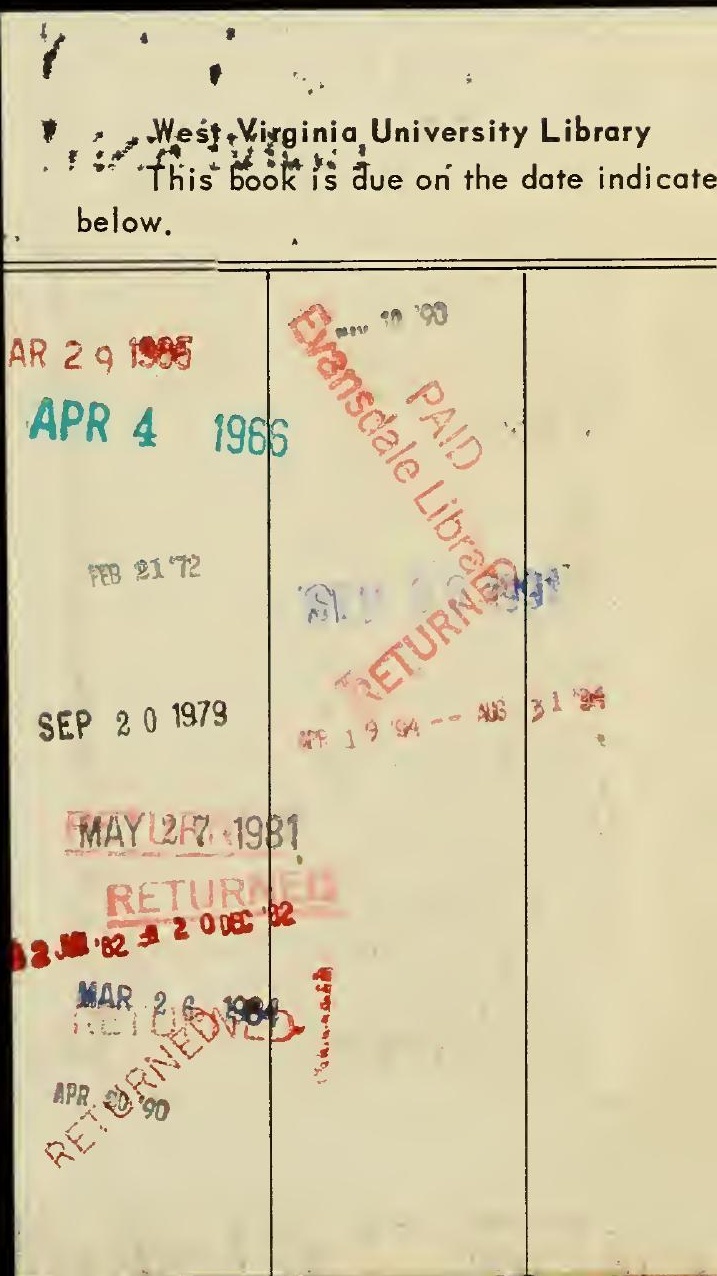



\title{
Bulletin No. 31
}

\section{WESI VIRGINIA}

Agricultural Experiment Station

\author{
MORGANTOWN, W. VA.
}

\section{CATALOGUE}

OF WEST VIRGIXIA

SCOLYTIDAE and their ENEMIES.

APliLL, 1893.

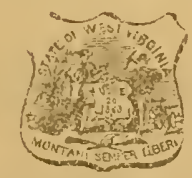

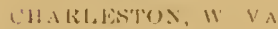

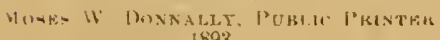




\section{BOARD OF REGENTS OF THE WEST VIRGINIA UNIVERSITY.}

Dislet
1
2
3
4.
5.
6.
7.
8.
4
10
11.
12
13

Tumb ol Retrent.

J. B. SOMMERVIJLE, CLARENUE L. SMITH, R. G. LYNN, JOHA C. YANCE. JOHN G. SCHILLING, EDWARD A. BENNETT, WIRT A. FRENCH, M. J KESTER, J. F. BLOWN, THOS. J FARNSWORTH, JOSEPH MORELAND, JOHN A. ROBINSON, DR. Wr. Mr. BROMN,
P. O. Address.

Wheeling. Fairmont. Glenville. Clarksburg, Spencer. Huntington, Princeton, Union. Charleston. Buckhannon. Morgantown. Patterson's Dépot. Kahletown.

\section{MEMBERS OF THE STATION COMMITTEE.}

JOIIN'A ROBINSON. JOSHPH MORELAND, DR. W. W. BROWN.

l'REST OF BOARD OF ReGENTS,

P'RESIDENT' OF THE l'NIVERSITY;

H. II TURNER, LL. D.,
C L SHITH, J. B. SOMMER VILLE, JOHN A. ROBINSON. TREASURER, - JOHN I. HARVEY.

\section{STATION STAFF.}

JOHA A. MYHES, PH. D, IF II. KA.TH, II

A. 1). IIUPKTAs.

1). 1). J0HNS(3, A. H.,

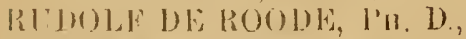
SITSTE, M. MAERS,
Director.

Iforticulturist aud Hirroscopist. lintomologist. Aericulturist. Cliemist. Stenographer and liook-keeper. 


\title{
CATALOGUE
}

() 1

\section{WEST VIRGINIA SCOLYTID E and their ENEMIES. 1 \\ With List of Trees and Shrubs Attacked.}

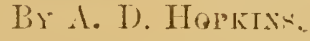

\section{IXTROIUUCTORY.}

\section{Damage Caused by Burk and Timber Beclles.}

The inmense damage to forest, shade and fruit tree caused by Bark and Timber Beetles belonging to the Scolytidix family, together with the importance of the timber and fruit interests of West Virginia has made it seem necessary that we should study the hahits of the different species found, and the extent and wharacter of the damage caused by them. While only a portion of my time has been derotet to this sturly, sullicient evidence has heen olitained to convince me that the destrutive powers of these minuteand apparently ingignificant beetles are fitr greatco than is generally supposed. ()wing to their obseure habits and the great labor and difliculty of collecting and studying them, comparatively litto has been known of the life histories of even the romnomest kinds. Therefore, it is our tlesire to call the attention of owners of timber, and others who are interested in the preservation of our foreste, to the great importance of a more extenderl knowledige of the number of sureces and the peculiar habits of each. Finerially is a mor gencral and technical knowlerlge necestary that some sncessful cfforts may be made towarks preventing the recurrence of widesumad devalstation of timber like that which hats occurred in difforent sections of the country within the last fifteon yealls.

Since $187 s$, vath areas of timber in the sprue forests of Naine,

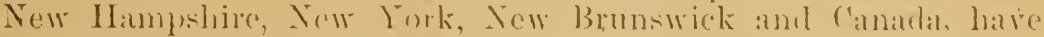

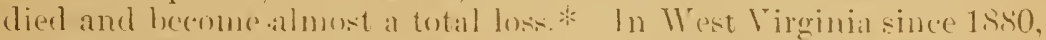
the Black sinuer on more than one: hundred thomsind actes of land has dien, cansing the loss of at least one nillion dellars. Sinee 1siss, an moprecedented death of trecs has ocenrerl among the dif-

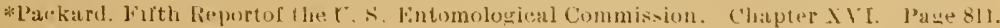


ferent kinds of Pine over an area of ten thousand square miles in IVest Virginia, Virginia and Maryland. Our magnificent Black Spruce forests, covering an area of over five hundred thousand acres, is agrain threatened, and if not checked will prove destructive to large areas of timber.

Frem my own observation during extended inrestigations in the Vest Virginia forests and from what I have seen of the habits of cortin European species, and from information obtained from Oberforester IV. Eichhoff and other high authorities on the subject in Germany, I am confident much, if not all, of the destruction of timber mentioned above has been due primarily to the attack of certain species of hark beetles.

\section{Number of Species in the Family Scolytida.}

According to Henshaw's lists and supplements of 1889 , this family includes 169 deacribed species. Numerous new species have since been discovered, until at present there are probably over 200 described and undescribed species in the rlifferent collections. The species taken by me in West Virginia since 1890 number 53 named and 27 unnared and new species. These I have divided into three popular groups according to certain peculiar habits of the adult insect; namely: Bark-beetles, Timber-beetles and Twig-beetles.

\section{Habits of Bark Beetles.}

As a rule, the adults of this group of Scolytids prefer to enter the green or partly dead bark on unhealthy, injured or dying trees, stumps, loys and tops of broken branches for the purpose of making mines or gatleries through the inner lark, in which to deposit their eggs. The minute white grub hatching from these eggs at once commence to feed upon the bark and usually proceed at right angles from the primary gallery and extend their mines through the hark until they have berome full grown, when they form pupre cases either in the outer sap-wood, inner or outer bark, according to the habits of the species. Ir due time the pupar change to adults like the parent form, and each indridual makes for itself an exit through the outro bark; thus the bark of a tree infested by bark beetles will be tound pierced with innumerahle round holes after the young beetles have fully developed and emerged.

The number of broork of bark-beetles vary from one to three accorling to the species and the favorable or unfavorable con ditions for their popagation. They pass the winter in different stares. Fome in the larval and pupal forms in the outer sap-wood or in the bank; others, as adults, concealed in the onter bark of living or dral trees. In this group, thirty-nine spectes have been

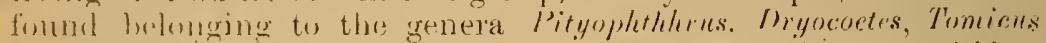

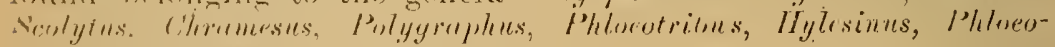

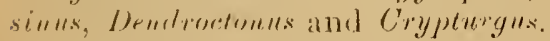

Whilo the majority of bark-beetles observed seem to prefer 
to attack unhealthy, injured or fallen trees, there is at least onr species (77) which seenrs to frefer attaleking living, vigorous trews, and there are others which are (alpal)!e of existing in perfectly creen bark without being serionsly ineonsenienced hy the: lluwing sajp or turpentine. When they attack the bark of a living tree, their coere galleries and larval mines through the inner hark have the oflect of chesking the llow of sal), thus causing an mulualthy (ondition of the tre. Other species having a preference for treers in this condition are attracted to it and enter the bark to extend their winding galleries and the death of the tree is the eertain result. In fact, many trees might resist the first attack sufficiently to recover alld other trees haring their health impaired from other caurs might regain their original vigor, were it not for the bark-bretles which are ever rearly to infest such treses and "ounteract all chances of re(a) very:

\section{Habits of Timber-Beetles.}

Timber-beetles like the bark-beetlen prefer, as a rule, to attark trees impaired in health, or those which have been recently felled, yot there are species in this group which seem to prefer to attack living trees. So far as I have observed, they all have a rlecided preference for grees or partly green woorl in which to extend their "pin-hole" tunnels. These tunnels or galleries are male hy the parent beetles for the purpose of forming proper receptacles for their eggs and favorable conclitions for the future derelopment of their young.

One class of this group consists of species helomging to the

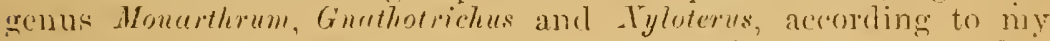
obscrration, deposit ther eggs in small excavations at more or less regular intervals along the sides of the galleries. These cavitios are just large enough to accommodate a single egg, and the grubs or larva hatching from them proceed to enlarge and extend the carity at right angles to the primary gallery. These side carities or chambers are only enlarged sufficiently to accommodate the lullgrown larva, pupa and young beetles. When the young bectles have sufficiently matured, they come out of the sirle chambers into the main gallery, and the entire brood emerge from the original entrace made by the parent bectle.

Another class of this group consisting of species belonging to the genus 1yleforus, bore into the wood in the same manner as those just mentioned, but instead of clepositing their eggs in cavities in the side of the galleries, they place them in groups within its walls. The young larive as a rule to not enlarge and extend the gallaries, but appear to feed upon a substance coming from the wood. Frequently eggs, larva of all stages, pupa, young and fully matured beetles will be found together in one gallery. It alvo aljpears that the hectles do not necessarily emcroe from the wood when matured, but may extend secondary and branching galleries in which they deposit eggs for another brood. One peculiarity observed with certain species of this classis the extreme small sizo of 
the males which are seldom, if ever, found outside of the galleries in which they have developed.

There is another class consisting of species belonging to the genus Platypuss which seems to partake of the bahits of both of the classes mentioned above, for I have olserved all'stages from eggs to fully matured forms in the same mine, and I have also found the fullgrown larva in side chambers evidently excavated by them.

The character of damage caucel by all of the species of the timber beetles is principally that resulting from their boring through the green wood of saw-logs and standing trees. The round, black holes so common in lumber and timline termed "pin-holes" or "worm boles." while not all caused liy sicolytids, they are to blame for certain kindis which render timber and lumber unmerchantahle The discoloration of wool termed "b] uing" jis also largely the result of the galleries former by the beetles in the green woor. The vacated galleries allowing air, water, and fungus germs to penetrate the wond of trees, logs, manufactured timber and lumber, not nnly cause the blue or colorer condition, lut a rayid decay of the woorl. Twenty-five species belonging to this group have heen observed.

\section{Habits of Treig-Bectles.}

The bcetles belonging to this group attack the términal twigs and sumall branches of living, dying and dead trees, in which they form galleries for the purpose of depositing eggs, and the larve feeel uyon the loark and wood. Species having this habit so far as I have observed belong to the generd Hypothencmus and Pityophthorus. Fifteen species leelonging to this group have been observed.

\section{The Clover Root-Beetle}

Is a species belonging to the Scolytid family which may properly be ealled a root beetle to distinguish it from those having different habits. I have not yet met with this species in our State, but from the fact that it is a common clover pest in adjoining States, it will doubtless be found within our horders.

\section{Special Investıgations.}

The destructive work of three species of Scolytids mamely the Destructive l'ine Bark Beetle (Dendroctomis frontritis), the Spruec Bark-beetlo (Polygruphus rufipennis), and European Fruit Bark-beetle (Scolytu, rugulnsus), has demanded special investigation requiring long and difficult journies through the extunsive forests, wild mountain regions, and other sections of the State. I have availed myself of the opportunity thus offered to not only study the habits of these destruetive species, but to also collect and study other members of the family to which they helong. Many interesting facts relationg to the fanily and their natural enemies have been discovcred and some imprortant experiments are now under way to ascer- 
tain the efficieney of rertain metherds of eombatting the most perenicions kimes ; ner of which is the importation of encmies of Eurnpean sonlytids to foed upon am reduce the mumbers of the destructivo Amorican species

These investigations and experiments are not yet sufficiently completed to justify the publieation of a detailed reprert of the work

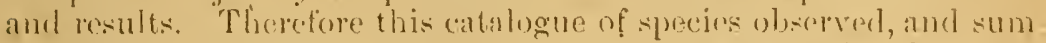
maly of notes redating to their lile history is sont out in ad ramre of popular holletios on forest and shate tree insects, which will comtain full aceonnts and illustrations of the principal injurious and leneficial species and detalled reponte of the investigations. It is also intended to sorve in part. as a catalogue of an exlabit allection of Serlytids and some of their enemier to be shown in the station cxhibit ly the lsociation of American Impicultural Colleges and Experincint station at the. World": Columbian Exprosition at Cliteigo.

\section{The Exwhitit 'ollertion'.}

Aside from showing the results of some special work in Entomology by the West Virginia Agricultural Exprerment Station, the exhibit referred to is intended to illnstrate as far as posisile the character of the rlanage cansed by Bark and Timber Bectles, ind the individual species to blame for ecrtain kinds of "pin-holes" in wond, ecrtain kinds of mines or galleries in the hark and other peculiar damage to timber and lumber, snch as "hluing" and premature deay, due to their boring in the green wool, and also to show somm of the native and imported encmies which are heing sturlial with : view of utilizing them in the lestruction of the injurious seolytids.

All of the sprecies mentioned in this catalogue could not he slrown in this exhibit on account of insufficient matrial for loth it and the exhibit collection of forest and sharle tres insests. to he shown with the forestry exhibit in the West Virginia building. It will also be understond that uniques and type specinens alre tim valualsle to place in an exhibit collection.

\section{The list of Inseits.}

All of the species mentioned in this catalogue have either been collected or lired by me since March, 1890, and the conclensed reference to hillits, collecting and breeding dates, localities, etc., are taken from my notes and records of ohservation.

The arrangement of the species of Coleoptera are accorting to Henshaw's list and supplements of 1889 , without regand to (hangess which have been marle since his list was issued. The If yenoptera are arranged in families as near as could be according to C'resson's synopsis of 1887.

Where the species of Coleoptera and Hymenoptera are simply named generioully, they are believed to be hew species. If, mun further study, this is found to he a jact, they will be describul and their namespublished in a sulserputent list.

Where a specien of predacions or prasitic insects is mentioned as being found with a species of Scolytid, it means that they were 
found in the mines or galleries of the Scolytids, but no further evidence was had that they actually attack them. Where the word attack is used, I have evidence that they are actually enemies of the species mentioned in comnection with them.

\section{List of Trees and Shrubs.}

The technical names of the trees and shrubs from which I have taken Scolytids has been made out and arranged hy my assistatht, Mr. W. E. Rumsey, from their common names as mentioned in my notes. Mr. Rumsey has also rendered efficient assistance in the jreparation of specimens of the exhibit.

\section{Acknowiledgcments.}

For the first determination of the largest number of the species of seolytids mentioned, I am under special obligations to Oberforester IV. Eichhoff, of Strassburg, Germany, who is probably the best aluthority in the world on the systematic stuly of this family.

For the determination of Hymenoptera, I an under obligations to 1)r. C. Y. Riley, Messrs. I. O. Howard and William H. Ashmead, of the Division of Entomology at Washington.

For the first determination of Coleopterous enemies, I am indelited to Dr. G. H. Horn, of Philadclphia, and to Dr. C V. Riley, of Washington.

For the naming and description of new species of Braconidae, I am under special obligations to Mr. William H. Ashmearl, of WVashington.

I desire in this comnection to mention the special kindness of the following named persons during iny recent visit to Germany for the purpose of collecting and studying the enemies of European Scolytidx: Mr. W. Eichhoft, of Strassburg, in giving valuable information and assistance hy letters of introduction and otherwise oluring my investigations in the Alsacian and Jorraine forests. Oherforester Strohmeyer and his son, Mr. H. Strohmeyer, of Hagenau, Ealsace, and Oherforester P'ilz, of Alhansweeler Lor'aine, in accomfranying nie and giring special privileges in the forests of which they have charge.

During my stay in the Kingdom of Saxony, Mr. Camillo F. Schanfus, Director of the Mrusem at Meissen, was specially kind in giving efficient aitl in oar search for the European Bark Beetle Destroyer, * in the King's forest near Moritzhurg.

'Through the kimluess of the C'urators of the Kensington Musenm at London, the Museum il Histoire Naturelle, at Paris. and the Musetim at Berne, I was permitted to examine the sturly collections of scolyticls. I alwo availerl myself of the opportunity of looking orer Mr. Eichlent"s elegant collection of Scolytich of the Wrold, in which many type specimens of American species were found.

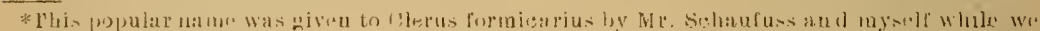

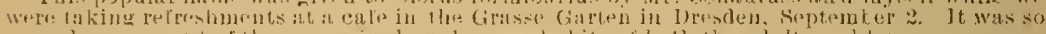
maned on accoubt of the lecognizes] pledacous habits of both the adults and harvac. 


\section{WEST VIRGINIA S COLYTID正}

Collected and Bred March, 1890, to .March, 1803.

\section{Order COLEOPTERA; Family scolytider.}

1.* Platypus quadridentatus, Oliv.

TIMIBER BEETLE. $\uparrow$

Enters green salp-wond near base of dying trees. Causes "pin-holes." hastens decay. Infests Black Oak, Chestnut.

Adults July 29, 30.

Enemies 128? 129?

Wayne and Wood counties.s.

2. Platypus compositus, Say.

JIMBEK BEETLE

Enters green sap and heart wood.

Causes "pin-holes" in word, hastens decay. Infests Black Oak, rugar Maple, Chestnut, Basswoor, Magnolia, Red Elm, Beerh, IVilı Cherry. Enemies 139.

Adult June 12 ; July 17, 21, 202, 29; Iugust 4, 10; Octoler 15; January :31. P'upue July 21, 22. Tarré July 21, 22; January 31. Eggs July 22, ; 1 ugust 10.

Counties, Tyler, Kamawha, WTetzel, Monongalia and Wood.

3. Corthylus punctatissimus, ' $/ \mathrm{imm}$.

TIMBER BFETLE.

Enter's work of green trees, causes the death of small trees. Inferts sassafras.

Adult vet. 14.

Ionongalia county.

* Numbres in heavy type iudicate that the specinen is slown in Fxhbit colection. tSee pace 1:33.

${ }_{\mp}$ Refer to numbers in this list.

Localitics where collected. 
4. Monartinum fasciatum, Say.

TINIBER BEE'CLE.

Enters green sap and heart wood of dying and dead trees, logs and stumps. Causes "pin holes,"* "bluing," + and hastens decay. Infests Pine, White Oak, Black Oak, Basswood, Beceh, Hemlock.

- Enemies 142?

Adult Feb. 20; Mar. 2; A pril 14, 15, 17, 18; May 18; July 21; Aug. 6,22 ; Sep. :

IVood, Wetzel, Tyler, Monongalia counties.

5. Monarthum mali, Fitch.

TIMBER BEETIE.

Enters green sap and heart woorl of lugs, stumpsand dying trees. Causes numerous small jin holes. Colors wood dark. Hastens decay. Infests Pine, White Oak, Black Oak, Red Oak, Jack Oak, Elm, Brech, Maple, Chestnut, Bassivood, Honey Lncust, Yellow Poplar. (Tulip), Buckeye, Morelln Cherry, Red Cedar, Hemlock.

Enemies 128.

Adults Feb. 20 ; Mar. 2; April 14 to $19 ;$ May 4, S, $30 ;$ July 16 , 20, 21, 24, 25, 29, 30; Aug. 4, 12 22; Sep. 3; Dec. 6; Jan. 31. Pupe July 21. Larvie July 21. Eggs July 21.

Wetzel, Wayne, Wood, Haneock, Monongalia and Kanawha counties.

6. Gnathotxichus retusus, Lec.

TIMBER BEETLR.

Enters sap-wood. Causes pin-holes and bluing. Infests White Pine, also other Pines.

Adult from Virginia near W. Va. line, October 21.

Adult dead in White Pine wood, Angust 29.

Nonongalia county and Trirginia.

7. Gnathotrichus materiarius, Fitch.

TIMBER BEETLE.

Enters green sap, wood at hase of stumps and dying trees. Causes "pin-holes." "bluing," hastens decay. Infests Pine.

Enemy 131 ?

Arlults May 18; July 13, 14; October 15; May 3; November 7. Wood, Hampshire, Marion, Monongalia counties. 
8. Pityophthorus minutissimus, $/ \mathrm{imm}$

BARK BEETLE. *

Enters green and deal hark on injured and deacl branches and topes of trees. Caluses slight, if any, damage. Infests Black (Dak. White? Oak, Jack ()ik, (hestnut ()ak, logerwood.

Enemy 114.

Arults June 1:; July 29; Decenber 24; January 27. Р'upa July 29) Larva July 29); Feloruary 12. Egogs July 29. $11^{r}$ ood and Monongalia Counties.

9. Pityophthorus sp. a.

B.IRK LEETHE.

Enters green bark of tops and branches injurerl or boken by storm. Hastens death of top and brandeles attacked. Infests White and other Pines.

Adults April 30.

IV ond county.

10. Pityophthorus pullus, $/ / 1 m m$.

BAHK BEETLE.

Mines uncler partly green bark on dying trese, branches and tops. liastens death of trees? Infests Pines.

Enèmies 149, 151 .

Arlults April 30; May 3, 4, 6, 9, 20, 30; Soptember 5, 12. Pupar May 30 Tarval May 80.

Hampshire, Hardy, Wood and Monongalia counties.

11. Pityophthorus, sp. b.

BARK BEETIE.

Inabits unknown. Collected on bark of deal Maple.

- Arlult May 27.

Monongalia county.

11: Pityophthorus plagiatus, Le..

Tomicus plagiatus, Lec. (\. 1). H.)

IBARK IZEETT.E.

Mines under green bark on tops and branches of injured and lying trees, broken branches, ete. Hastens death of injured trees. Infests Pines. Enomies, 101 .

Aclults, May ?, 6, 1s; Octeber 10, 14.

Wood, Hampshire and Monongalia counties. 
12. Pityophthorus sparsus, Lee.

Tomicus sparsus, Lec. (A. D. H.)

BARK BEETLE.

Mines in green bark on tops of injured and dying trees, broken branches, etc. Hastens death of trees. Infests White Pine, also other Pines.

Adults, April 30; May 9; Septembur 12 Papæ September 12 Wood county.

Eggs April 30. Adults emerged July 1.

13. Pityophthorus cariniceps? Lec.

TW1G BEETLE.

Mining under bark and in wood of terminal twigs of young dying spruce. Damage unknown. Infests

Adults, Arigust 29. Black Spruce.

Randolph county.

14. Pityophthorus confinis, Lec.

BARK BEETLE.

Mining in outer and inner bark on dead trees, and under green bark on injured trees Probably hastens death of trees. Infests Pines.

Enemy, 156 .

Adults April 30 ; May 4, 6, 20; June 21, 24; July 13. Larvæe, Pupe and adults October 14.

Wood, Hampshire and Monongalia counties.

15. Pityophthorus consimilus, Lec.

BARK BEETLE.

Mines under green bark on dying trees and injured shrubs or vines. Hastens death of shrubs. Intests Sumach, all of the species of the genus Rhus.

Enemy 155.

Adults June 27; July 22; August 4; November 8; October 15. Pupa June 27; October 15 . Larva June 27; October 15; December 7 .

Wood, Kanawha, Tyler, Marion and Monongalia counties. 
16 Pityophthorus hirticeps". Lar.

$(=$ ? neri spuries. . 1. 1). H.)

TWIG BEETL.K.?

Mines under hark and in wood of terminal twigs on young tres. Damage unknown. Infests Black Spruce.

Adults A ugust 29.

Riandolph connty.

17. Pityophthorus sp. c.

BARK BRETKE?

In bark of dying trees. Damage unknown. Infests Black spruce.

Adults.June 23; A A gust 29.

Enemy 94.

Randolph and Pendleton counties.

18. Pityophthorus lautus, Eich.

BARE BEETLE.

Vining under bark on injured branches and trigs. Damage unknown. Infests Pine.

Ailults June 29; July 30. Iarvie July 30.

IIrood county.

19 Pityophthorus puberulus, Lec.

BARK BEFTLE.

Mining under bark on dead trees.

Damage unknown. Infests Pine.

Arlults July 20.

Enemy 151.

Marshall county.

20 Pityophthorus sp. d.

'TTIG BEE'TLE.

Mining in bark and wood of dying twigs on green trees. Seems to cause the death of the twigs. Inferts Pines.

Enemies 83? 151

Adults May 3; June 29: July 13, 30. Bred-Egg= May 3. Iarver, Pupe and Adults July 13. Larsa July 13, 30. Hampshire and Wond counties.

21 Pityophthorus sp. e.

TWIG BEFTLE.

Mining in bark and wood of dying twigs on healthy trees. Probably kills twigs. Infests Pine.

Adults, Pupe and Larve June 29.

Woorl county. 
22. Pityophthorus. tuburculatus, Eich.*

BARS BEETLE,

Mining under bark of terminal twigs

Aclult bred Oct. 28.

on young trees. Infests Black Spruce.

Randolph county.

23. Pityophthorus s.p. f.

Adults June 29.

Woorl county.

24. Pityophthorus sp.g.

BARK BEETLE.

Miring under green bark on injured tops and branches. May hasten death of injured trees. Infests White Pine, also other Pines.

Adults April 30.

Wood county.

25 . Pityophthorus sp. h.

BARK BEETLE.

Nining under bark on dead branches.

Adults Dec. 4 .

Infests Apple.

Monongalia county.

26. Hypothenemus eruditus,- Westw.

TWIG BEETLE

Mines in pith and wood of clead twigs and vines. Infests Honeysuckle.

Ailults bred March 18.

Wood county.

27. Hypothenemus sp.a.

TWIG PHETIE.

Mining under bark on small deat

Adults Dec. 4; Oct. 23. branches. Infests Apple.

Monongalia county.

28. Hypothenemus sp. b

TWIA BEETLE.

Mining in outer end of twigs on clead trecs. Infests White Walnut, Black IValnut.

Enemy 116.

Adults Mar. 2 ; April 24. Bred April 25. May 30 . Eggs Má 30. Monongalia county.

*Su determined by Mr. Vichloulr. 
29. Hypothenemus sp. c.

TWIA BEETLE.

Mining in buds and ends of twigs of

Ailults December t. cut hranches. Infests Apple.

IIonongalia county.

30. Hypothenemus erectus, Lec.

TWIO BEETLE.

Jining in pith and wood of rine.

Adult bred April 19. P'upie Mareh.

Infests Honeysuckle.

IVood county.

31. Hypothenemus sp d

TWIF' BEETLE.

Mining in bark and wood of dying twigs on healthy trees. Infests

Adults June ??. Pine. (P. inops.)

IVool county.

32. Hypothenemus dissimilis, Zimm.

TWIG BEETLE.

Mining in pith and wood of dead

Ailult: October 15 . twigs. Infests Hickory.

Marion county.

33. Hypothenemus sp e

Ariults Oct. 15.

TW:I REETLE.

Mining in pith and woor of twigs lislled hy twig girdlel onciderus cingulatu. Infest. Hickory

Marion county.

34. Hypothenemus sp.f.

JWIA BFE'TLE.

Adults Oct. 10.

Jetierson county.

3.5. Hypothenemus sp. g ·

TWL BEETLE.

Mining in twigs killed by oak pruner (blaphidion parallelum?) In-

Alult Dee. 24. fests 11 hite Oak.

Wrood county. 
36. Xyloterus retusus, Lee.

TIHBER BEETLE.

Enters green sap-wood of dying trees. Causes large pin holes. Hast-

Aduits Aug. 10. ens decay. Infests Large-toothed Aspen.

Monongalia county.

37. Xyloterus bivittatus, Kirhy.

TIMBER BEETHE.

Enters green sap wood of logs, stumps and dying trees. Causes great damage to saw logs. Produces pin holes. Causes "bluing" and hastens decay. Infests Black Spruce and Hemlock.

Euemies 138, 139 ?, 154 ?.

Adults May 8, 9; June 1; July 7, 8, 9, 11; August 30; September 1. Pupe June 1; July 9. Larve June 1; July $9,11$. Eggs May 8,9 .

Tucker, Grant and Randolph counties.

38. Xyloterus scabricollis, Lec.

TINBER BEETLE.

Enters green sap wood of dying pina trees. Causes "pin holes," "bluing" and hastens decay. Infests Pines.

Adults May 3, 4.

Hardy and Pendleton counties.

39. Xyloterus politus, Say.

(Nyloterns unicolor, Eich.)

TIMBER BEETLE.

Enter's green wood of logs, stumps, dying trees and wounded places on green trees. Causes black "pin holes" in wood. Tery injurious to outer portion of wood. Hastens decay. ('olors the wood. [nfests Beech, Black Oak, White Oali, Rerl Oak, Hemlock, Sugar Maple, Rerk Maple, Chestnut, Magnolia, Ehm, Hickory, Ash, White Birch, Black Spruce.

Enemies 128, 140 ?.

Adults March 29, 30; April 12, 17, 29, 30; May \&, 9; June 1; July 10, 16, 24, 26, 29, 30; August 10. Eggr July 17. Adults emerging July 24.

Wood, Grant, Tucker, Hancock, Tyler, Wayne and Monongalia counties. 
40. Cryphalus n. sp., (Eich.)

Adult April 15.

Flying.

Wood county.

41. Xyleborus pyri, Peck.

TIMBER BEEILE

Enters green sap and heart wood of logs, stumps, injured and liring trees. Causes black "pin holes," a serious clamage to lumber. Infest Hemlock, Beech, Birch and Reil Oak.

Adults May \&, 9. Larva June 1. Eggs May \&, 9.

Grant county.

42. Xyleborus sp. a.

TIMIBER TEETIE.

Enters wood of stumps. Causes

Dead adult January 31. hlack "fin holes." Infests Codar.

Moungalia county.

43. Xyleborus obesus, Lee.

TIMBER BEL'TIE.

Enters green wood of logs. Causes large black "pin holes." Probably causes considerable damage to oak timber and lumber. Infests Black Oak, Beech and Hemlock.

Adult March 3; July 6, \&. Puper and larvex July 6, S. Preston, Grant and Monongalia counties.

44. Xyleborus celsus, Eich.

T11BER BEETI.E.

Enters wood of logs and dying trees. Infests Hickory.

Adults April 30 ; May 20. Enenı 160 ?

Wood county.

45. Xyleborus fuscatus, Eich.

TIMBER HEETTE.

Euters green wool near base of stumps and dying trees. Causes "pin holes." Hastens death of tree. Infests Black Onk and Hickory.

Adults July 10, 24, 29, 30 . Enemy 163?

Wayne, Grant, Woorl and Monnngalia rounties. 
46. Xyleborus, sp. $\mathrm{b}$

Adults July 7. 30; Jan. 27.

Enters green sap woorl near base of dying trees and stumps. Causes numerous black "pin holes." Hastens decay. Infests White Oak, Chestnut Oak, Black Oak, Jack Oak. Enemy 165 ?

Wayne, Woor and Monongalia counties.

47. Xleborus sp. c.

'T TMBER BEE'TLE.

Er.ters green wood at base of injured trees. Causes "pin holes." Hastens

Adult July 29. decay. Infests Jack Oak.

Wood county.

48. Xyleborus sp. d.

TIMBER BEETLE.

Enters green sap rood near base of dying trees. Causes numerous small "pin holes" in wood. Infests Black Oak, Hickory and Chestnut.

Adult July 10, 29; Sep. 3; Oct. 10.

Monongalia, Wayne, Grant and Marion counties.

49. Xyleborus xylographus, Say. (Tylebnrus Saxesenii, Ratz.)

TIMBER BEETI.E.

Enters green wood on felled trees and injured or dying wood on green trees. Probably hastens death of injured trees. Infests Apple.

Arlults, Pupx, Larva, Eggs October 11; December 4, 6; March 2. Manongalia county.

50. Xyleborus, sp. e.

Adult flying April 14.

TIMBER BEETLE?

iVood county. 
51. Xyleborus pubescens, //imm.

T'IBIBEK 13ELT:

Enters green say and heart wood of stumps, logs and dying trees. Causes numerous black "pin-holes." Hastens death of trees. Infests White Oak, Chestnut, Black Oak, Buckeye, Magnolia, Basswood, Cultivater Cherry, Honey Locust, Jack Oak.

Enemy 163.

Adults April 14, 18, 27; May 4, 20; September 3; Adult, Pupe, Larvi, Eggs July 21, 29.

Wood, Wetzel and Monongalia counties.

52. Xyleborus, sp. f.

THMBER BEETLE.

Enters green sap wood at base of dying trees. Causes "pin holes," "bluing." Hastens decay. Infests Pine.

Adults, Pupre, Larve July 24.

Monongalia county.

53. Xyleborus, sp. g.

A dults Flying.

TIMBER BEETLE?

Wood county.

54. Dryocoetes autographus Patz.

(Dryococtes septentrionis, Mann.,

BARK BEETLE.

Nines under green bark on logs. stumps and dying trees. Hastens reath of injured trees. infests Black Spruce. Norway Spruce. Enemies 86, 87, 90, 124? 13।?

Adults irarch 15, 26, 28, 29, 30, 31; May 8 ; June 18, 20. Pupa August 29. Larva March 31; July 11; August 29, 30; September 1. Eggs July 11; September 1.

Randolph, Monongalia, Tucker and Grant counties.

55. Dryocoetes, n. sp.

BARK BEETLE.

Mines under green bark on stumps, logs anil dying trees. Hastens death of trees. Infests White and Black Birch, Wild Cherry.

Enemies 124? 142?

Adults May S, 9; July 7,9. Jarrie May S, 9. Eggs July 7, ?. Grant county. 
56. Dryocoetes affaber? Mann.

BARK BEETLE.

Mining under bark on dearl trees.

Adult July 9.

Infests Black Spruce

Grant county.

5\%. Dryocoetes granicollis, Lec.

BAKK BEETLE.

Mining under green bark on stumps, logs, and dying trees. Hastens death of trees Infests Black Spruce.

Adults March 29; May 9; June 1, 24; July 9, 11; August 28, 29; Septemker 1. Pupæ August 29. Larva September 1. Randolph, Tucker and Grant counties.

58. Tomious calligraphus, Germ.

BARK BEE'TLE.

Mining under green bark on stumps, logs, injured and dying trees. Hastens death of trees and may cause thir death. Infests all of the Pines.

Enemies 105, 132? 136? 143? 151

Adults May 3, 5, 8, 15; June 23, 24; July 13, 27; October 2, 15, 19, 22; November 6. Pupx June 23; July 13; October 19. Larve June 23 ; July 13. November 6. Eggs May 3, 8; August 10. Actults mining in nuter sap-wood October 15.

Wood, Hampshire, Pocahonfas, P'ndleton, Monongalia, Hardy and Wirt counties.

59. Tomicus cacographus, Lec.

BARK BEETLE.

Mining under green bark of logs, stumps, injured and dying trees. Hastens death of injured trees. May rause the death of trees. Infests all the Pines, Black Spruce, Norway Spruce.

Enemies 88, 89, 105, 131?, 132? 135 ?, 144?, 149, 151, 155, 161 .

Adults A pril 1; May 3, $8,9,15,18,20,23$; June $13,14,23$, 24, 29; July 9, 13, 14, 24. 28; August 12, 29. Pupse .June 13, 14, 23, 24, 24; A ugust 29; November 7. Larva May 18; June $13,23,24$; July 28 ; November 7 . Eggs May 3, 8, 9; July 13, 20, 28. Adults emerging from bark July 14 ; November 7 . Mining in outer sap-wook A ugust 12.

Wood, Hardy, Marion, Monongalia, Grant, Hampshire, Pendleton and Randolph counties. 
60. Tomicus pini. Say.

B.IRK BEETLE.

Mining uniler green bark of logs, stumps, injlired and dying trees. Hastens death of trees. Infests all of the pines. Norway Spruce.

Encmies 105, 121?, 125?, 159, 161 .

Arults May :3, 4, 30; July 14, 20, 27; November 7. P'upar July 20, 27. Larva May 3, 30; November 7. Eggi Niay 3.

Ifarly, Wetzel, Marshall, Pocahontas, Hampshire, Pendleton and Monongalia counties.

61. Tomicus avulsus, Eich.

BARK BEETLE.

Mines under green bark and in outer sap-wood of logs, stumps and dying trees. Hastens death of trees. Infests White and other Pines.

Enemy 156.

Adults May 4, 6, 8; June 23. Eggs May'S

Woorl, Hampshire and Pendleton counties.

62. Tomicus cælatus, Eich.

(.ylchmus riclatus, Eich.)

BARK IBEETLE

Mines under green bark on logrs, stumps, living and dying trees. Hastens death of trees. Infests all of the pines, Black, Spruce, Norway Spruce.

Enemiès 107, 121?

Arults Nareh 15; Anril 30; May' 3,11 ; June 4, 12; July 1, 4, $13,20,2+, 27$; September 1, 30; October 1t, 17, Novemher 13. Pupa July 13, 21. Larvie Nay IS; July 13, 21. Egos April 30; Nay 1.

Adults emerged July 1. Eggs June 12; July 21

Monongalia, Wirt, Wood, Wetzel, Marshall, Hampsinire, Randolph eounties.

(63. Tomicus plagiatus, Lee. Equals 11a this list.

64. Scolytus quadri spinosis, Say.

HICKURY B.ARK BEETIE.

Mfining under green bark on logk, stumps and dying trees. Infests Hickory .

Encmies $\$ 5,92,15 \mathrm{~S}$

Adults July 22; August 10. Pupe April 29, 30. Larrat Julv $22,24,29,30$; August 10 ; Norember 7 . Eggs July 24; A ungust 10.

Tyler, Wood and Monongalia counties. 
65. Scolytus muticus, Say.

IIACKBERRY BARK BEETLE.

Nines in bark and wood of felled and dead trees, dead branches on living trees. Hastens decay of wood. May hasten death of idjured trees. Infests Hackberry.

Enemies 91 ?; 95?.

Adults emerged May 2. Larve full grown October 23; February 28.

- Wood and Monongalia counties.

66. Scolytus rugulosus, Ratz.

EUROPEAN FRUIT BARK BEETLE.

Nines under green bark of injured dying and living trees, cut and broken branches. Hastens death of trees. May be the primary cause of death of trees. Infests Apple, Cultivated Cherry, Plum, Peach, Pear and Quince.

Enemies 81, 97, 98, 99, 100, 108, 110, $142,146 ?, 153,155,157 \mathrm{a}, 158,166 ?$.

Adults A pril 15, 17, 29; May S, 19; June 16, 17, 20, 21, 22, 24, $25,26,29$; July 1, 20, 24, 25, 26, 30, 31; A ugust 12, 13, 29; September 7. Pupæ January 1, 17; April 17; June 1; July 20; August 22. Larve January 1, 17; A pril 17; June 1, 20, 22, 25; July 20; August 22; October 23; December 24. Eggs June 16, 17, 21, 22, 25; July 26; August 29; September 27. Observed adults emerging June 1, 22; July 26; August 22. Observed adults copulating September 7; October 5 .

Monongalia, Wood, Cabell, Tyler, Harrison, Marshall counties.

6\%. Chramesus icoriæ, Lec.

BARK BEETLE.

Mining under partly green bark on cut branches and tops of dying trees. Iofests Hickory.

Enemies 147?, 161.

Adults April 23, 29; June 24, 25; October 15.

Wood and Marion counties. 
68. Polygraphus rufipennis, Kirby.

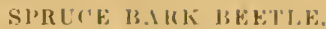

Mining under green hark on logs. tops, stumps, broken branchss, lising, injured and dying tress. Catuses death of trees. A destruntive sinecues. Inferts Black spruce

Enemies $84,93,96,10: 3,104,112$ 113. 115 ?, 121 ? , 122.2?, 12 ? ?, 133 ?, 134 ?, 137 ?, $150,151.155,157,161$, 162,164 .

Mlult: Mareh 26, 25, 31; May $8,9,12$, 30; June 4, 21, 22, 28; July $7,8,11,12$; August 12, 29, 30; Septemher 1, 2, 14; Getober 22, 2S; November 31 Pupe Nay 30. Larvie IIarch 26, 29, 31; June 23; July 9, 12; September 1. Eggs May 9; June 23; July 8, 9. Adults (leveloped from eggs between May 12 and July 22.

Randolph, Grant, Tucker, Pendleton and Monongalia counties.

69. Phlœotribus liminaris, Harr.

BARK BEETLE.

Nining undér green bark on living, injured and dying trees, broken. branches, logs, stimps, etc: Hastens leath of trees. May prove a troublesome pest. Infests peach, cultivated cherry, wild cherry. Adults hibernate in outer bark of living trees. Enemy 15irt.

Adults April 3, 17; May 11, 15, 30; July 13, 20, 24; November 26 ; February 7. Pupe July 13, 24. Larra July 13, 21. Eggs May 30 ; July 13.

IVood, Marshall and Monongalia counties

70. Phlœotribus sp. a.

Adult flying May 18.

BARK BEETLE?

Wood county.

71. Phlœotribus, sp. b.

IBALK BEETLE.

Ender bark on dead trees. Infests Red Cedar.

Aclult Octoher 22.

Iarion county. 
72. Phlœotribus, frontalis, Oliv.

BARK BEETLE.

Mining under green bark on living, injured and dying trees, and broken branches. Hastens death of trees. Infests Mulberry.

Adults hibernate in outer bark on living trees.

Enemy 145?.

Adults Ap'ril 9, 23; June 24; July 20, 29; December 4. Pupæ June 2t; December 4. Larve June 24; December 4. Wayne, Wetzel and Monongalia counties.

193. Hylesinus aculeatus, Say.

ASH BARK BEETLE.

Mining under green bark of logs, stumps and dying trees. Hastens death of trees. Infests Ash (black).

Adults June 20; July 24; A ugust 10. Pupæ June 20; July 24. Larve June 20; July 24; A u sust 10 . Eggs June 20. Monongalia, Randolph and Tucker counties.

74. Hylesinus opaculus, Lec.

ELM BARK BEETLE.

Mining under green bark on logs, stumps, dying trees and broken - branches. Hastens death of trees. Infests Elm. Fnemy 151.

Arlults July 6, 21; August 4, 10 Pupæ July 21. Larvæ July 21 ; August 4.

Wetzel, Hancock and Kanawha counties.

75. Phloosinus dentatus, Say.

CEDAR BARK BEETLE.

Mining under green bark on logs, stumps, tops of injured and dying treés and broken branches. Hastens death of trees. Beneficial in separating bark from posts, thus preventing decay of sap-wood. Infests Red Cedar.

Enemies 88, 102, 1119, 148, 149.

Adults April 29; May 4, 8, 20, 23; June 1, 9, 14, 18, 24, 25; July 4 ; August 1,5 ; October 8 ; November 8 . Pupre June 1, 18; August 5, 8 . Larve May 23; June 1; Noromber 8; August 5. Eggs April 29; May 4, 8. Bred: first eggs May $S$. Lirvie full grown June 1. Adult; emerged June 9: Second broud eggs July 15 to 18. Pupre August 5.

Wood, Grant, Monongalia and Hampshire counties. 
76. Dendroctonus terebrans, Oliv.

BARK BEETLE.

Mining in green bark and turpentine on living and dying trees, logs, and stumps. Hastens death of trees. May be primary cause of death of trees. Infests all of the pines.

Alults May 3, 4, 5 ; June 23; July 13, 21 ; August 10; Septenbér 23; October 10, 14; November S. Pupæ July 13, September 2S. Larve June 23; July 13, 21; August 10; October 14. Eggs May 3, 4. Bred: Larva July 13. Adult emerged September $2 S$.

Hampshire, Monongalia, Pendleton, Hardy, Marion and Wood counties.

77. Dendroctonus frontalis, Zimm.

THE UESTRUCTLVE PINE BARK BEETLE. Mining under green, sappy bark on living, healthy trees. Primary cause, within four years of the death of over $\$ 1,000,000$ worth of timber. Very destructive. Infests all of the pines. Black Spruce, Norway Spruce. Enemies 82, 106, 111, 121?, 151, $156,161,168$.

Adults May 3, 4, 5, 18, 22; June 23, 24; July 11, 13, 17, 2.; August 10; September 12, 29; October 10, 12, 21; November 7 ; December 1 . Pupse May 3, 4, 5; August 10; October 10, 21; Larve May 3, 4, 5, 30; July 12; August 10 ; October 10, 21. Eggs May 5, 20; July 24; November 7 . Breeding dates: adults entered green bark Nay 1S; young larva found May 30. Pupre July 24. Larve collected November 7 . Adults emerged December 1.

Hampshire, Hardy, Tucker, Randolph, Pendleton, Monongalia, Wood and Greenbrier countics.

78. Crypturgus pusillus, Gyll.

(Crypturgus atomus, Lec.)

BARK BEETLE.

Mining in bark on dying and dead trees. May hasten death of trees. Infests the pines, Black Spruce.

Enemy 161 .

Adults March 20, 26, 25; June 24; July 9, 13; August 30; October 1 . Larve March 26, $2 S$.

Wood, Tucker, Randolph, Grant, Hampshire and Monongalia counties.

79. Hylastes, sp.

BARK BEETLE.

Adult May 3.

In bark of dying pines.

Hardy county. 
80. Hylurgops glabratus, Zett.

(Hylurgops pintfex, Fitch.)

BARK BEETLE.

Mining under green bark at base of dying trees. Also on logs and stumps. Hastens death of trees. Infests the pines.

Adults May 3, 4,5; June 29. Pupe October 4. Eggs May 3, 4, 5. Bred: adults entered bark May 1S, young larre June 13. Full_grown larvæ July 14.

Wood, Hampshire, Pendleton, Grant and Monongalia counties.

\section{ENEMIES OF SCOLYTID ZE}

Including Predaccous, Parasitic, and other Species

Found with Members of this Family.

Collected and bred March 1890 to March 1893.

Order HYMENOPTERA; Family ICHNEUMONID

81. Hemiteles scolyti, Ashm., sp. n., MS.

With Scolytus rugulosus (66) In

Adults bred April 20.

dead peach twigs.

Wood county.

\section{ORDER HYMENOPTERA; FAMILY BRACONID AE}

82. Bracon pirsodis, Ashm.

PRINARY PARASITE.

Attacks Dendroctonus frontalis (77) in pine bark.

Aduits bred January 29. Cocoons November 7 .

Monongalia county.

83. Rhyssalus pityophthori, Ashm., sp. n:

With Pityophthorus sp $d$ (20.) In

Adults bred July 29 . pine bark.

Described by William H. Ashmead, "Canadian Entomologist," XXV., page 69.

Wood county. 
S4. Spathius claripennis, Ashm., sp. n.

P'HIMARY PARASITE.

Attacks Polygrepheus rufipenuis (is) in Spruce bark.

Adults bred April 20. Cocoons March 26; Sep. 26; Nor. 31; Larvio May 4.

Describer by $\mathbf{W m}$. H. Ashmead, "Canadian Entomologist," XXV., page 72.

T'ucker and Monongalia counties.

85. Spathius unifasciatus, Ash. n. sp.

PRIMI RY PARASITE.

Attacks Scolytus 4-spinosus (64),

$\Lambda$ dults bred April 29. Hickory Bark.

Described by Wm. H. Ashmead "Canadian Entomologist," XXV., page 72 .

Wood county.

S6. Spathius brachyurus, Ash. n. sp.

(Si.)

PRIMARY PARASITE.

Attacks Dryocoetes autrigraphus in Spruce bark.

Adults bred April 6; Nov. 10. Cocoons March 15; A pril 6.

Described by Wm. H. Ashmead "Canadian Entomologist," Vol. XXV., page 73.

Monongalia county.

88. Spathius Canadensis, Ash. n. sp.

PRIMARY PARASITE.

With Phloeosinus dentatus (75) Red Cedar and Tomicus cacographus (59) in White Pine.

Adults bred May 2, 10. Cocoons March 31; April 14, 18, 23. Wood county.

89. Spathius pollidus, Ash n. sp.

PRIMART PARASI'IE.

Attacks Tomicus cacoyraphus (59) in

Adult bred June 23. Pine Bark.

Described by Wm. H Ashmead in "Canadian Entomologist," Volume XXV., Page 74.

Wood county.

90. Spathius tomici, Ash. n. sp.

PRIMARY PARASITE.

Attacks Dryocsetes autographus (54) in Spruce bark.

Adults bred April 6; Cocoons March 15.

Monongalia county. 
91. Spathius brunneus, Ashm.

With Scolytus muticus (65) in HackAclults bred. Cocoons May 2.

berry bark.

Kanawha county.

92. Lysitermus scolyticida, Ash. n. sp.

$$
\text { PHIMARY PARASITE. }
$$

Attacks Scolytus 4-spinosus (64) in Hiskory bark.

Adults bred from Cocoons, April 30.

Wood county.

93. Lysitermus sp?

PRIMARY PARASITE.

Attacks Tomicus plagiatus (11a. 63) in Pine bark.

Adults bred. Cocoons, October 14.

Monongalia county.

94. Cænophanes pityophthori, Ash, n. sp.

PRIMAKY PARASITE.

Attacks Pityophthorus sy. c., (17) Polygraphus rufipennis (68) in Spruce bark.

Adult flying May 2. Cocoous February 24. (Adults bred) Larve October 25. Described by $\mathrm{Wm}$. H.- Ashmead, "Canadian Entomologist" XXV. Page 78.

Ionongalia and Wood counties.

95. Helcon legator, Say.

PRIMAKY PAIRASITE.

With s'colytus muticus (65) in Hackberry.

Adults bred. Cocnons, Miay 2.

Wood county.

96. Cosmophorus, hopkinsii n. sp., Ash. MS.

PRIMAET PARASITE.

Attacks Polygraphus rufipenuis (6S) Larve in Spruge bark.

Adults flying August 29. Adults bred September 14; Oct. 25. Randolph county.

ORDER HYMENOPTERA; FAMILY CHALCIDIDAE.

97. Eurytoma bicolor, Walsh.

$$
\text { PRIMARY PAKASITE. }
$$

Attacks Scolytus rugulosus (66) in

Adults A ugust 8. Apple bark.

Monongalia county. 
98. Eurytoma sp. a.

Alult Aug. 19.

PRIMARY PARASITE

IVith scolytus rugulusus (66) in Apple bark.

Monongalia county.

99. Eurytoma sp. b.

Adult Aug. 12.

PRIMARY PARASI'E.

With Scolytus rugulosus (biti) in $A$ p ple bark.

Wood county.

100. Eurytoma sp. c.

PRIMART PARASITE.

Attacks Scolytus rugulosus (66) in Apple, Peach, Cherry and Plum bark

Adults March 4, 25 ; A pril 17, 25; June 1S, 22; July 25: Aug. 12. IVood county.

101. Eurytoma sp d.

Aclult bred Oct. 14.

P'RTMAKY PARASITE?

Attascks Tomicus plagireins (11a.63) in I'ime bark.

Ifonongalia county.

102. Eurytoma sp. e.

PRIMARY PARASITE,

Attacks PMluensimus derutatus (75) in Cedar bark.

Adults hred May 4 ; July 24 . Larve April 14. Arlult emerged May 4.

Wood county.

103 Eurytoma, sp f.

PRIMARY PARASITE.

Attacks l'olygraphus rnfipenmis (6S) I arrar in Black Spruce.

Adult Sept. 26.

Randolph county.

104. Lochites sp. a.

PRIMARY PARASITE.

Attacks Polygrophens rufipmenis (6.S) in Spruce bark.

Arlults March 31; April 14; May 9; July 13; Sept. 1. Pupae A pril 2. Larre Warch 26, 28.

Randolph, Grant, Tucker and Monongalia counties. 
105 Lochites sp. b.

Adults July 20. Aug. 12, 22.

PRIMARY PARASITE.
Attacks Tomicus cacographus (59)
Tomicus calligraphus (5\$) Tomicus
pini (60). in pine bark.

Wood and Marshall counties.

106. Lochites sp. d.

\author{
PRIMARY PARASITE \\ Attacks Dendroctonus frontalis (77) \\ in Pine bark.
}

Adults bred January; Larvæ December; October 10.

Monongalia county.

107. Lochites, sp. e.

PMIMARY PARASITE.

Attacks Tomicus celatus (62 in Nor-

Adults July 13. way Spruce bark.

Monongalia county.

108. Chiropachys color, Linn.

PRIMARY PARASITE.

Attacks Scolytus rugulosus (66) in Apple, Peach, Plum and Cherry bark.

Adult March 17, 21; April 15; May ; June 18, 22, 26; July $20,22,25$; August 8,12 ; November 8; January 17. Larve January 17.

Wood, Monongalia and Marshall counties.

109. Pteromalus sp. b.

PRIMARY PARASITE.

Attacks Phloeosinus dentatus (75) in Cedar bark.

Adult April 18.

Woorl county.

110. Platygerrhus sp.

PRIMARY PARASITE.

Attacks Srolytus rugulosus (66) in

Adults April 29.

Apple bark.

Wood county.

111. Heydenia unica, Cook.

PRIMARY PARASITE.

Attacks Dendroctonus frontalis (77) in Pine bark.

Adults January . Larve November 7.

Monongalia county. 
112. Spintherus sp.

PRIMARV P'ARASITE.

Altacks Polygruphus rufiprnnis (6S) in Spruce bark.

Conon: September 1. Adults bred. Randolph county.

119. Trigonoderus sp.

PRIMARY PARASITE.

Attacks Pulygraphus rufipennis (68) in Spruce bark.

Adults April 14; June 23; July 10, 12; Sept. 1. Larve March 26. Randolph county.

114. Chalcid.

Belongs to sub-family Pteromalinæ.

Ashmead (in letter).

Bred from adult Pityophthorus min-

Adults emerged March 10. utissimus (8).

Monongalia county.

In a letter dated March $16 \mathrm{th}, \mathrm{Mr}$. WWm. H. Ashmead says this is the first observation of the kind made in the family Chalcidider.

115. Decatoma sp.

With Polygraphus rufipennis $(68)$ in

Adults July 12. Spruce bark.

Grant count $y^{*}$.

Order HYMENOPTERA; Family PROCTOTRYPID丑

116. Aphalonomia hyalinipennis, Ash.

With Ilypothenemus, sp. U. (2S) in

Idults April 24.

White Walnut twigs.

Monongalia county.

Order HYMENOPTERA Family CHALCIDID E.

(Secondary Prirasite.)

117. Tetrostrichus, sp. a.

Adults June. Larre March 29.

SECONDARY PARASITS?

Bred from Thanasimus larve in

Sumach, and Thruasimus dubins (151)

larvie in spruce bark.

Tucker county. 
118. Tetrastrichus sp. b.

SECONDARP PARASITE?

With Scolytus rugulosus and Chalcid parasites of S., rugulosus, in Apple bark.

Aduts April 25. June 23, 26.

Wood county.

\section{Order DIPTERA; Family MUSCID ZE.}

119. Tachina sp.

Bred from adult Thanasimus dubius (151:)

Larva emerged from beetle August 12, changed to pupa August 13.

Adult emerged August 2s.

Monongalia county.

Predaceous Enemies, etc.

Order COLEOPTERA; Family STAPHYLINID王.

120. Quedius peregrinus. Grav.

Adult August 29.

Randolph county.

PREDACEOUS?

With Scolytids under Spruce bark.

121. Homalota sp.

PREDACEOUS.

With Tomicus crelatus (62) Tomicus pini (60) Polygraphus rufipennis (68) in Spruce and Dendroctonus frontatis (77) in Pine bark.

Adults September 1, 22, 25; October 21, 22; April 17, 14; May 4, 30; July 13.

Rindolph, Monongalia, Tucker, Wood and Pendleton counties.

122. Xantholinus cephalus, Say.

PREDACEUUS?

On bark of Black Spruce tree infested with Polygraphus rufipennis; (68.)

Adults Inarch 29.

Tucker county. 
12:). Baptolinus longiceps, Fal.

PREDACEOES.

With P'olygraphess mefipenuis (fis) in Arlult September 1, March 28. liandolph and Tucker countiss.

124. Siagonum americanum, Melsh.

PREDACEOUS.

With Dryocres autogrerphus (5t) in Spruce bark, and Dryocutes "1. sp.. (55) in Birch bark.

Adults May 8 ; July 11 . Iarve May 8.

'Tucker and Grant counties.

12). Staphylinid larvæ.

Larræ July 20.

Wetzel county.

PREDACEOUS LARTAE.

With Tomicus pini (60) in Pine bark.

\section{Order COLEOPTERA; Family ENDOMYCHID AE.}

126. Endomychus biguttatus, Say.

With Scolytids under Pine hark.

Adults October 15; December (i.

Marion and Monongalia counties.

\section{Order COLEOPTERA; Family COLYDID ZE.}

127. Aulonium tuberculatum, Lec.

Adults July 13.

With Scolytids in Pine bark.

Hampshire county.

128. Colydium lineola, siạ.

PREDACEOL'S,

With Plutypus quadridentetus, (1) in sap wood of Black Oak. I'yluterus politus (39) in Red Maple. Houthrthum mali $(5)$ in Jack Oak, and in Scolytid mines in Pine bark.

Arults July 18, 29, 30; Angust 19, 27 ; September 12. Hampshire, Wayne, Tyler, Monongalia and Wood counties. 
129. Sosylus costatus. Lec.

PREDACEOUS.

With Platypus quadridentatus (1) in Black Oak.

Adult July 29.

iv ayne county:

130. Philothermus glabriculus, Lec.

With Scolytids under Spruce bark.

Under dead Locust bark.

Adults August 29; Octoher 11.

Randolph and Monongalia counties.

\section{Order COLEOPTERA; Family HISTERID璱}

131. Hister parallelus, Say.

With Dryccetes autographus (54) in Spruce; Tomicus sucugrapluus - (59) and Guntlentrichus maleriurius (7) in Pine.

Adults May 18; June 24, 29; July 20; November.

Monongalia, Woud and Marshall counties.

132 Hister cylindricus, Payk.

With Tomicus cocogroplus.s (59) and Temicus calligraphines (5.5) in Pine bark

Arlults May 5, 8; A ugust.12.

Wood and Pendleton counties.

133. Paromalus bistriatus, Er

With Polygraplens rufipenuis (68) in Spruce bark.

Adults July 11; August 30.

Ranrlolph and Tucker counties.

134. Paromalus difficilis, Horn.

With Polygroplues rufipcumis (6S) and

Dryicotes "ffuber (56) in Spruce bark.

Aduits July 8, August 28; September 1. Pupæ July 8.

Randolph county.

135. Plegaderus transversus, Say. :

With Tomicus cucographess (59) in Pine bark.

Adults June 24, 29; July 20.

Wootl and Marshall counties. 


\section{Order COLEOPTERA; Family NITIDULIDÆE.}

136. Colastus unicolor, sily.

With l'ityophthorus confinis (14) and Trumicus calligroplues (5S). Inder.

Ariults May 4. bark on dead P'ine.

P'endleton county.

137. Epuræa truncatella, Mann.

With Polygrophus rufipennis (6S) in Spruce bark.

Adults March 26; July.

Tucker and Grant counties.

138. Ips fasciatus, Oliv.

With Xyloterus biviltatus (37) on Spruce logs.

Adult: May $S$.

Grant county.

139. Nitidulidæ larvæ

Ips fuciutus?

With Tyloterus bivittutus (37) in Spruce wool. Platipus compositus (2) in Basswood, and (yyllene liobinir larvae in locust bark on living tree.

Larva May 14; June 1; July 9, 21.

Wood and Grant counties.

140. Ips sanguinolentus, Oliv

PREDACEOUR.

With Iyloterus politus (39.) Under Sugar Maple bark, also feeding on Black Walnut sap.

Adults A pril 5; May 9.

Wood and rrant counties.

141. Rhizophagus dimidiatus, Mann.

With Scolytids under Spruce bark.

Adults March 26; September 1.

Randolph and Tucker counties.

142. Rhizophagus bipunctatus, say.

With Scolytus rugulosus (66) in

Apple bark. Nonarthrum fresciatum

(4) in Beech bark and Dryocrite's ".

$s p$. (55) in Birch bark.

Arlults March 21; April 1S; May.

Wood, Pendleton and Monongalia counties. 


\section{Order COLEOPNERA; Family IATHRIDITD 画}

143. Corticaria elongata, Hun.

With Tumicus calligrapluns (5S) under hark on Pine.

Arlults July 27.

Wist county.

Order COLAOPTERA; Family TROGOSTTID FE,

144. Nemosoma cylindricum, Le.

With Tomicus cacographus (59) in Pine Bark.

Adults May 20

Wood county.

145. Tenebrioides corticalis, Melsh.

Under bark on , dead Apple tre and with Plilcestrilus fromlulis (72) in bark of live Mulberry.

Arlults September 7. Pupæ April 25. Adult einerged May 12. Monongalia and Wood counties.

Oroler COLDOPTWRA; Family MAIACHID FE

146. Attalus scincetus, Sav.

With Scolytus rugulosus (66) in apple bark.

Arlutt March 21

Mon ngalia county.

Order COLAOPTRRA; Family CLERIDZE.

14\%. Elasmocerus terminatus, Say.

PREDACEUUS.

With Chramesus icorie in IIickory.

Allult flying Jume 22. Adults bred from Hickory April 23.

Wooktanel Monongalia counties.

148. Cymatodera bicolor, Say.

PKEDACEUUS.

With Phloeosinus demiatus? (75). in Cedar bark.

Whult May 15.

Wool eounty.

149. Clerus quadrisignatus, Oliv. var nigripes, Say.

l'REDACEOUS.

With. Fumicus cacographus (59) and Pityophthorus puluus (10) in Pine bark; with Plilocosinus dentatus (75) in Rerl Cerlar.

Adult April 29; May 4, ?.

(iriunt county. 
150. Thanasimus trifasciatus, sidy.

PREDACEOS

With Poljeraphus rufifonns (bis) under Spruce bark

Ailult March 29; August 29; Jarve March 2S. Ramblolph amel 'Jucker counties.

151. Thanasimus dubius, Fab.

PRKI)ACEOIS:

Attacks Tomucus cacosraphuts (59), Tomacus calligraphus (58), Dendroitonus frontalis (7T), Pitrophthorus pullui (10), P. puberutus (19), J', trophthorus sp. a. (20), in Pine bark. Polygraphus rufipennis (63), in Spruee bark, and Hylesinus opaculus (74) in Elun bark. Enemy? 117. Enemy 11?.

Alults May 2, S, 30; 1 ugust; September 1 ; Ostober $6 ;$ Novemher; Lalla March 28, 31; May 3;.July 21, 30; A ugust 2y; Se\}tember 7 ; October 6. 10, 21.

Randolph, Tucker, Hampshire, Monongalia, Grant and Wood Counties.

152. Clerus formicarius, L.

$=$ ? Tianasumus formicarius, $\mathrm{L}$.

TIE EURUPEAN JAHK BEETLE DESTROYH.

Destructive to Senlyticls in Eurropean Coniferous forests. One thourand live speeimens of adults, larra and pupar. imported to Amerien in Octoler, 1892, by the West Virginia Experiment Station, ailed by owners of pine foresti First adultis collected by me in Crovermment firr est of Pinus Sylvestris near Hayenau, Alsace, Germany. August. 2?, 1892. First adults set free in Amelican pine forest near Morgantown, IV. Va. On October, 10, 18!). This species was introduced to prey upon Dendroitonus frontalis and wher speries of scolytidu.

153. Thanasimus sp. d.

PREHACEOTS.

With Siolytus rugulosus (6it) on Ap-

Adult June 17. ple tree.

Upshur county. 
154 Thaneroclerus sanguineus, Say.

PREDACEOUS.

On Hemlock Stump with Xyloterus

Adult May 8.

bivittatus (37)

Grant county.

155. Phyllobænus dislocatus, Say.

PREDACEOUS.

Attacks Polygraphus rufipennis (68.) in Black Spruce, and Pityophthorous consimilis (15) in Sumach (Rhus glabra.) With Scolytus mogulosus (66) in Apple bark.

Adults bred June 16, 20, 22; Dec. 7 .

Randolph, Wood and Monongalia counties

156. Clerid larvæ sp a.

PREDACEOUS.

With Dedroctonus frontalis (77) Tomicus avulsus.(61) and Tomicus

Larvæ June 23, 29; Oct. 14. cacographus (5.9) larvæ in Pine bark.

Wood county.

157. Clerid larvæ sp. b.

PREDACEOUS.

With Polygraphus rufipennis (68) lar-

Larvæ July 23; March 26. væ in Spruce.

Tucker and Wetzel counties.

$15 \%$. Clerid larvæ sp. c.

Larvæ March 2; July 13.

\section{PREDACEOUS}

With Phloeotribus liminaris (69) in Wild Cherry, and Scolytus rugulosus (66) in Apple bark.

Monongalia county.

158. Clerid Larvæ sp. d.

PREDACEOUS.

With Scolytus rugulosus (66) in Apple hark, Scolytus quadrispinosus (64) in Hickory bark and Scolytus muticus (65) in Hackberry bark.

Larve March 2; July 20; October 7; November 23. Marshall and Monongalia counties. 
159. Clerid larvæ sp e.

Larrae July 20.

PREITACETS

Tomicus prin $(60)$ in pine bark.

Marsiall county.

Order CLEOPATRA; Family TENEBRIONIDÆE.

160. Hypophloeus Cavus, Lec.

PREDACEuUs.
With Xyleborus ce'sus (14) in
Hickory.

Aclult July 22. Hickory.

'Tyler county.

161. Hypophloeus parallelus, Melsh.

\section{PREDACEOUS}

With Polygraphus mifpennis (68) in Spruce bark, Tomeus cacograph's (59) Tomicus pini (60) Dendroctomus frontalis (77) Crypturgus pussillus (7S.)

in Pine bark, and Chranesus icurice

(67) in Hickory bark.

Adults March 26; May 5, 18; June 24, 25. 29; July, 8, 13, 14, 20, 24; August; November 7. Larvie August 12; October 12. Grant, Hampshire, Wood, Hardy, Munongalia, Pendleton, Randolph, Marshall and Tucker counties.

162. Hypophloeus thorracicus, Melsh.

I'REDACEOUS.

With Polys rraphus rufiponnis (68) in

Achult August 2!). Sirucue bark.

Rimdolph county.

1(i3. Hypophloeus bicolor, Melsh.

P'REDACHOUS.

With Aylcborus pubescens (51) in Chestnut wood, Xyleborus fuscat?

Adults May 20; July 30. (45) in Black Oak wood.

Woud counity.

164. Tenebrionid larvæe.

PREDACEOUS.

With Polygrapluzs rufipennis (68) in

Larva Aug. 30. Spruce bark.

Randolph county. 
165. Hypophloeus sp. a.

Adult July 30.

IVood county.

PREDACFOUS.

With Xylcborus sp. b. (46) in Chestnut Oak wood.

166. Anthicus pubescens, Lec.

With Scolytus rugulosus (66)

Adults April 25. in Plum bark.

Wood county.

\section{FUNGACE}

168. Cylindrocola dendroctoni, Pk. (n. sp.) Fungus Disease. On and with dead adults, larve, and pupre of Dendroctonus frontalis under Pine bark. The fungus probCollecter, May 3, 4, 5. ably kills the insect Peck.

Hampshire. Hardy and Pendleton Counties.

Species described in Flora, of W. Va., (Bulletin 24), page 51 


\title{
TREES AND SHRUBS INFESTED BY SCOLYTIDAE.
}

\author{
Plants.
}

Insects.

\section{MAGNOLACEF.}

Cucumber Tree, Marynolac acuminata, I.

Tulip Tree, "Yellow Poplar."

Platypus compositus, Say,

Liriodendron tulipifer a, L. Monarthrum mali, Fitch,

\section{TILIACEZI.}

Basswood,

Iilie Amoricana, L

Platypus com:positus, Say,

Monarthrum fasciatum, Say,

Monarthrum mali, Fitch

Xyleborus pubescens, Zimn.

\section{SAPINDACE $Æ$.}

Buckeye

$\begin{array}{ll}\text { Aesculus octandra, Marsh., } & \text { Monarthrum mali, Fitch, } \\ \text { (Aesculus fava, Ait.) } & \text { Xyleborus pubescens, Zimn. }\end{array}$

Sugar Maple, Acer succharum, Marsh. Platypus compositus, Say. (Acer saccharinum, Wang.) Xyloterus politus, Say,

Red Maple, Acer rubrum. L.

Monarthrum mali, Fitch, ?Pityophthorus sp. b., Xylotus politus, Say, 


\section{ANACARDIACEA.}

Stag-horn Sumach,

Rhus typhina, L · · Pityophthorus consimilis, Lec., 15

Smooth Sumach,

'Rhus glabra, L Pityophthorus consimilis, Lec., 15

Dwarf Sumach,

Rhus copallina, L. Pityophthorus corsimilis, Lec., 15

Poison Ivy,

Rhus Toxicodendron. L Pitynphthorus consimilis, Lec. 15

Poison Sumach, Poison Elder, Rkus venenata, L.

Fragrant Sumach,

Rhus Canadensis, Marsh Pityophthorus consimilis, Lec. 15

Pityophthorus consimilis, Lec. 15

\section{IEGUMINOS坐.}

Honey Lncust,

Giledutschia triacanthos, L. Monarthrum mali, Fitch. 5

Xyleborus pubescens, Zimm. 5 l

Apple.

\section{ROSACE Æ.}

Pyrus nalus, I.

Pityopthorus sp. h.

25

Hypothenemis sp. a. 27

Hypothenemus sp. c. $2 ! 4$

Xyleborus xylographus, Say. 4!)

Pear,

Scolytus rugulosus, Ratz.

Peach;

Pyrus communis, L.

Persica vulgaris, Dec.

Scolytus rugulosus, Ratz.

66

Scolytus rugulosus, Ratz. 66

Phloeotribus liminaris, Harr, 69

Quince,

Cydonia vulgaris, Dec. Plum,

Prunus domestica, L.

Cultivated Cherrry,

Prunus vulgaris, 'L.

Scolytus rugulosus, Ratz.

Scolytus regulosus, Ratz.

Monarthrum mali, Fitch,

Xyleborus pubescens, Zim. 51

Scolytus rugulosus, Ratz. $\quad 66$

Phloeotribus liminaris, Harr. 69

Wild Black Cherry,

Prunus serotina, Ehrh. Platypus compositus, Say.

Dryocoetes n. sp.

Scolytus rugulosus, Ratz. $\quad 66^{3}$

Phloeotribus liminaris, Harr. 69

\section{CORNACE AS.}

Flowering Dogwood,

Cornus florida, L.

Pityophthorus minutissimus, Zim. 
Black Ash,

\section{OLEACE正.}

Fraximus sambuiafolia, Lam. Ayleterus politus, say.

Hylesinus aculeatus, Say.

\section{LAURACEZE}

Sassafras,

Sassafrus, officinale, Nees. Corthyluspunctatissimus,Zimm. 3

\section{URTICACEAE}

Slippery, or Red Elm,

Ulmus fu/tu, Michx. Platypus compositus, Say.

White Elm,

Llmus Americana, L. Hylesinus opaculus, Lec.

Xyloterus politus, Say.

Monarthrum mali, Fitch.

Hackberry, "Hoop Ash,"

Coltis ocididentalis, I.

Black, or Red Mulberry,

Scolytus muticus, Say.

Morus mbra, I.

Phlœotribus frontalis, Oliv.

\section{JUGLANDACEAE}

White Walnut, Butternut,

Black Walnut,
Juglans cinerea, L.
Hypothenemus sp. 1).

Hickory,

$$
\text { Juglans nigra, L. }
$$

Hypothenemus sp. b.

Hicoria, Raf.

Carya, Nutt.

Xyloterus politus, Say

Nyleborus celsus, Eich

Xyleborus fuscatụs, Eich.

Xyleborus sp. d.

Hypothenemus dissimils,

$$
\text { Zimm. }
$$

IIypothenemus sp. e.

Scolytus quadrispinosus, Say. 64

Chramesus icorix, Lec.

\section{CUPILIFER $\mathbb{E}$}

Sweet, or Black Birch, Betuialenta, L.

Xyleborus pyri, Peck

Dryocotes n. sp.

Nyloterus politus, Say.

White Birch,

Betula populifolia, Ait. Xyloterus politus, Say

Dryocotes n. sp. 
White Oak,

Quercus alba, L.

Chestnut Oak,

Quercus prinus, I,

Red Oak,

Qucrius rubra, L.

Scarlet Oak',

Quercus coccinea Wang.

Black Oak.

Quercus tinitoria, Bart.

Jack Oak,

Qucras migra, I,

Chestnut,

Custanca satiza, Mill.

var. Americuna, Sarg.
Monarthrum fasciatum, Say, 4

Monarthrum mali, Fitch,

Pityophthorus minutissinus, Zimm.

Hypothenemus sp. f.

Hypothenemus sp. g."

8

34

35

Xyloterus politus, Say, $\quad 39$

Xyleborus sp. b.

46

Xyleborus pubescens, Zimm.

Pityophthorus minutissinus, Zimm.

Xyleborus sp. b.

8

46

Monarthrum mali, Fitch,

Xyloterus politus. Say,

Xyleborus pyri, Peck.

Pityophthorus minutissimus,

$$
\text { Zimn. }
$$

Platypus quadrilentatus, Oliv. 1

Playtypus compositus, Say, 2

Monarthrum fasciatum, say, 4

Monarthrum mali, Fitch, 5

Pityophthorus minutissimus, Zimm.

Xyloterus politus, Say,

Xylehorus obesus, L+c.

Xyleborus fuscatus, Eich.

43

Xyleborus sp. b.

Xyleborus sp. d.

Xyleborus pubescens, Zimm. 51

Monarthrum mali, Fitch

I'ityophthorus minutiesimus, Zimm.

Xyleborus sp. b.

8

Xyleborus sp. c.

Xyleborus pubescens, Zimm.

Platypus quadridentatus, Oliv. 1

Platypus compositus, Say, 2

Monarthrum mali, Fitch, 5

Xyloterus politus, Say, $\quad 39$

Xyleborus, sp. d. 48

Xyleborus puhescens, Zimm. 51 
Beech,

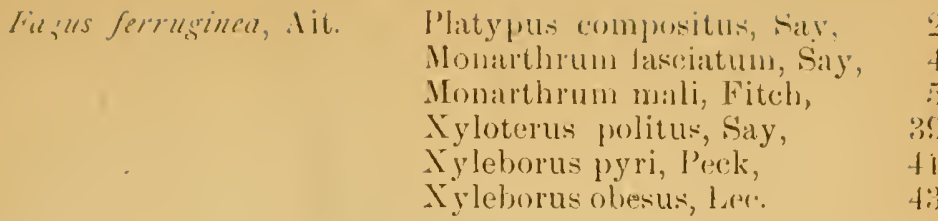

\section{SALICACE ZE.}

Litrge-touthed Aspen,.

Populus gr andidrintata, Michx. Xyloterus retusus, Lec.

\section{CONIFER}

Rierl Cerlatr.

Juniperus Virsiniana, [. Monarthrum mali, Fitch,

Phlnertribus sp. ib.

Phloeosinus dentatus, Sily.

Nyleborus, sil. a.

White I'ine,

I'inus strobus, l.

Ginathotrichus rutusus, Lee.

(imathotrichus meteriarius, Fitch,

Pityophthorus sp. a.

Pityophthorus sparsus, Lec. 12

I'ityophthorus sp. d.

Tomicus callographus, ferm. is

Tomicus cacographus, Lec. $\quad 59$

Tomicus pini, Say, 60

Tomicus avulsus, Eich.

Tomicus caelatus, Eich. $\quad 62$

Dendroctonus terebrans, Oliv. 76

Dendroctonus frontalis, $\mathrm{Zimm} .79$

Crypturgus pusillus, Gyll. $\quad 80$

Hylurgops ghibratus, Zett. \$2

I'ines.*

White Pine.

P'tuus strolius, I.

Loblolly P'ine,

Pinus Tatda, I,

Pitch P'ine, Pinus rigida, Miller.

Table Mountain Pine,

Pinus pungens, Michx.

Scrul, Pine,

Pınus Virginiana, Miller.

(P'inus inops, lit.)
Honarthrum fasciatum, Sily, 4 Ionarthrum mali, Fitch, 5

Gnathotrichus retusus, Lec., of

(inathotrichus materiarius,

Fitch,

Pityophthorus, sp. a,

Pityophthorus, pullus, Zimm. 10

Pityophthorus, plagiatus, Lec. $11 a$

Pityophthorus, sparsus, Lec., 12

Pityophthorus, confinis, Lec., 14

Pityophthorus, lautus, Eich, 18

*'l'be different pines mentioned are altacked by one or more of the insects named under this bial. 
Yellow Pine,

Pityophthorus, puberlulus, Lec. 19

Pinus echinata, Miller,

Pityophthorus, sp. d.,

(Pinus mitus, Michx.)

Black Spruce,

Pityophthorus, sp. e, 21

Pityophthorus, sp. f., 23

Pityophthorus, sp. g., $\quad 24$

Hypothenemus, sp. d., 31

Xyloterus scabricollis, Lec., $\quad 38$

Xyleborus sp. f., $\quad 52$

Tomicus callographus, Germ. 58

Tomicus cacographus, Lec., $\quad 59$

Tomicus pini, Say 60

Tomicus avulsus, Eich., $\quad 61$

Tomicus caelatus, Eich., $\quad 62$

Dendroctonus terebrans, Oliv., 76

Dendroctonus frontalis, Zimm. 77

Crypturgus pusillus, Gyll. 78

Hylastes sp., $\quad 79$

Hylurgops glabratus, Zett, $\quad 80$

Picea Mariana, (Mill.) B. S.

$\mathrm{P}$.

(Pacea nigra, Link.)

(Abies nigra, Poir.)

Norway Spruce (foreign.)

Picea excelsa, De candolle. Dryocoetus autographus, Ratz. 54

Hem'ock,

Tsuga Canadensis, Carr.
Tomicus eacographus, Lec. 59

Tomicus pini, Say.

60

Tomicus cxlatus, Eich.

62

Dendroctonus frontalis, Zimm. 79

Crypturgus pusillus, Gyll. $\quad$ So

Pityophthorus cariniceps, Lec. 13

$\begin{array}{ll}\text { Pityoyhthorus hirticeps, Lec. } & 16 \\ \text { Pityophthorus sp.c. } & 17\end{array}$

Pityophthorus tuberculatus, Eich,

Xyloterus bivittatus, Kirby.

Xyloterus polytus, Say,

Dryocoetes autographus, Ratz, 54

Dryocoetes affaber, Mann., 56

Dryocoetes granicollis, Lec. $\quad 57$

Tomicus pini. Say, 60

Tomicus cælatus, Eich. $\quad 62$

Polygraphus rufipennis, Kirby, 68

Dendroctonus frontalis, Zimm. 79

Crypturgus pusillus, Gyll. SO

Monarthrum fasciatum, Say. 4

Monarthrum mali, Fitch, 5

Xyloterus bivittatus, Kirby 37

Xyloterus politus, Say, $\quad 39$

Xyleboris pyri, Peck 41

Xyleborus obesus, Lec. $\quad 43$
Tomicus cacograplus, Lec: 59 


\section{INDEX.}

Anthicus pubescens, 166 .

Aphalonomia hyalinipennis, 116.

Attalus scincetus, 146.

Aulonium tuberculatum, 127.

Baptolinus longiceps, 123.

Bracon pirsodis, S2.

Cielsophanes pityophthori, 94.

Chiropachys colon, 108.

Chramesus icorice, 67, 147, 161.

Clerid larve sp. a., 156.

Clerid larve sp. b., 157.

Clerid larvas sp. c.. 157a.

Clerid larre sp. d., 158.

Clerid larve sp. e., 159.

Clerus tormicarius, 152.

- Clerus quadrisignatus var. nigripes, 149.

Colastus unicolor, 136 .

Colydium lincola, 128.

Corthylus punctatissimus, 3.

Corticaria elongata, 143.

Cosmoyhorus hopkinsii, 96.

Cossonus corticola, 167 .

Cryphalus 11. spe, 40.

Crypturgus pusillus, $78,161$.

Cylindrocola dendroctoni, 168.

Cymatoder:a bicolor, 148.

Decatoma sp., 11.;.

Dendroctonus frontalis, $7 \%, 82,106,111,121,151,156,161,1$ (is.

Dendroctonus terebrans, 76 .

Dryocnetes affiaber, 56,134 .

D)ryocoetes autographus, 54, s6, 87, 90, 124, 131.

Dryocoetes granicollis, 57 .

Dryocoetes septentrion'ls (See Dryocoetes autographus)

Dryocoetes n. sp., $\quad 55,124,142$.

Elasmocerus terminatus, 147 .

Endomyshus biguttatus, 126.

Eupraa truncatella, 137. 
Eurytoma bicolor 97.

Eurytoma sp. a. 98.

Eurytoma sp. b. 99.

Eurytoma sp. c. 100.

Eury toma sp.d. 101.

Eury toma sp. e. 102.

Hury toma sp. f. 103.

Gnathotrichus materiarius, 7, 131

Gnathotrichus retusus, 6 .

Helcon legator, 95.

Hemiteles scoyti, 81.

Heydenia unica, 111.

Hister cylindricus, 132.

"Hister parallelus, 131.

Hamalota sp. 121.

Hylastes sp. 79.

Hylesinus áculeatus, 73 .

Hylesinus opaculus, 151.

Hylurgops glabratus, 80 .

Hypophloeus bicolor, 163.

Hypophloeus cavus, 160.

Hypophloeus parallelus, 161.

Hypophloeus thoracicus, 162.

Hypophloeus sp. a. 165.

Hypothenemus dissimilis, 32.

Hypothenemus erectus, 30.

Hypothenemus eruditus, 26.

Hypothenemus sp. a. 27.

Hypothenemus sp. b. 28, 116

Hypothenemus sp. c. 29.

Hypothenemus sp. d. 31.

Hypothenemus sp. e. 33.

Hypothenemus sp. f. 34.

Hypothenemus sp. g. 35.

Ips fasciatus, 138.

Ips sanguinolentus, 140 .

Lochites sp. a. 104.

Lochites sp. b. 105.

Lochites sp. d. 106.

Lochites sp. e. 107.

Lysitermus scolyticida, 92.

Lysitermus, 93.

Monarthrum fasciatum, 4, 142

Manarthrum mali 5, 128, 157

Nemosoma cylindricum, 144 .

Nitidulidida larva, 139.

Paromalus bistriatus, 133.

Paromalus difficilis, 134.

Philothermus glabriculus, 130 .

Phlerosinus dentatus, \%o, s8, 102, 109, 148, $14 \%$. 
Phluninu-lontalio, $72,145$.

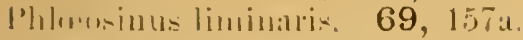

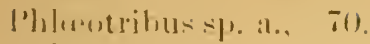

Phlowtrihus sp. li. 71.

Phyllobatome dislexattus, 15is.

l'ityophthorus (armiceps, li:

l'ityophtheres comlinis, 14,136 .

l'ityophthosus ansimilis, $15,15 \pi$.

l'ityophthorus hirtirepse, 11 .

P'itrophthorus lautus, 1 s.

P'ityophthorus minutissinus, 8, $11-1$

Pityophthorus puborulus, $-19,151$.

l'ityophthorus pullus. 10, 14!1. 151.

l'ityophthorus sparsus, 12.

Pityophthorus tubereulatus, ye.

Pityophthorus sly a., ?

l'ityouhthoris sp. b.. 11 .

l'ityophthoms sp ('., $17,94$.

l'ityolhthorts sp. 1.. 20, $83,1,1$

P'ityphthoms sle. t.. 21.

P'ityouhthorus ip. 8., 22.

l'ityophthorus ij. g., 20t.

l'ityopluthorus sp. h., 2.5.

l'atygerrhus sp., 110 .

Platypus ionupesitus, 2, 139 .

Platipus yuadridentatus, $1,128,10 \%$.

Plegarlerus transversus, 135.

Polygraphus rufipennis, $68,44,46,103,104,112,113,115,121$. $122: 123,139,134,137,150,151,155,15 \%$. 161. 1102,164

P'teromalus sfe. b., 10!?.

Pteromalinte, $11 \mathrm{t}$.

Quedius pererrinus. 120.

Rhizophagus hipunetatus. 14:.

Rhizophagus dimidiatus, $1+1$.

lihysialue pityophthori. 68.

solytus t-rpinosus, 64, sis, ?2, 15.

scolytus muticus, $65,91,95,15 \mathrm{~s}$.

solvtus rugulostri, $66,81,97,5), 99,100,105,110,118,142,146$

$1.53,155,157 \mathrm{a}, 15 \mathrm{R}, 166$

sonlytick, $120,122,126,127,125,1: 3), 1+1,167$.

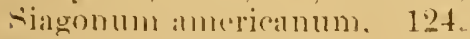

sosilus costatus, $12 ! !$.

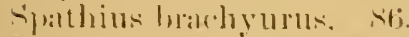

-inthius hrumneus. 91

ifuthius canadensis: ss.

sirathiuir polliclus, s!

Spothins tomice, st).

sprathins mifasciatus. sis.

spintherus, sp. 112. 
Staphylinid larva, 125.

Tachina, sp. 119.

Tenebrioides corticalis, 145.

Tenebrionid larva, 164.

Tetrastrichus, sp. a. 117.

Tetrastrichus, sp. b. 118.

Thanasimus dubius, $117,119,151$.

Thanasimus formicarius, 152.

Thanasimus trifasciatum, 150 ).

Thanasimus, sp. d. 153.

Thansimus larva, 117.

Thaneroclerus sanguineus, 154 .

Tomicus avulsus, 61,156 .

'Tomicus cacouraphus, 59, 88, $89,105,131,132,135,144,151,156,161$.

Tomicus crelatus, $62,107,110,121$.

'Tomicus calligraphus, $58,105,132,13 t, 143,149,151$.

Tomicus pini, $60,105,121,125,159,161$.

Tomicus plagiatus, $11 \mathrm{a}, 63,93,101$.

Tomicus sparsus, 12.

Trigonoderus, sp., 113.

Tantholinus cepalus, 122.

Xyleborus celatus (see Tomicus ('itlatus).

Xyleborus celsus, 44,160 .

Ayleborus fuscatus, $45,16:$.

Xyleborus obesus, 43.

Xyleborus pubescens, 51, 16:?.

Xyleborus pyri, 41 .

Xyleborus saxesenii (see Xyleborus xylographus).

Xyleborus xylographus, 49 .

Xyleborus sp. a., 42.

Xyleeborus sp. b., $46,165$.

Xyleborus sp. c., 47.

Xyleborus sp. d., 48.

Xyleborus sp. e., 50 .

Xyleborus sp. f., 52 .

Xyleborus sp. g., 5i3.

Ayloterus bivittatus. $37,138,139,1$ it.

Tyloterus politus, $39,128,140$.

Xyloterus retusus, 36.

Xyloterus scabricollis, 38.

Xyioterus unicolor (see Xyloterus politus). 



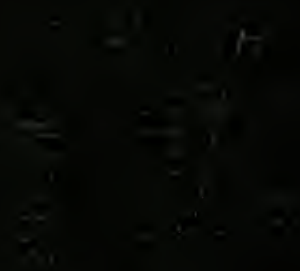

